\title{
CHARACTERIZATION OF THE CHEMICAL COMPOSITION OF ATMOSPHERYC DEPOSITION
}

Mihaela Petrescu ${ }^{1}$, Elena Bucur ${ }^{1}$, Andrei Vasile ${ }^{1}$, Raluca Diodiu${ }^{1}$, Gabriela Geanina Vasile ${ }^{1}$, Valeriu Danciulescu ${ }^{1}$, Mihai Bratu ${ }^{1}$, Gheorghita Tanase ${ }^{1}$

${ }^{1}$ National Research and Development Institute for Industrial Ecology - ECOIND, Drumul Podu Dambovitei no 71-73, district 6, zip 060652, Bucharest, Romania

\begin{abstract}
Atmospheric deposition means the total mass of pollutants which is transferred from the atmosphere to surfaces (e.g. soil, vegetation, water, buildings, etc.) in a given area within a given time. Is considered to be a major process that removes pollutants from the atmosphere and an important source of nutrients and contaminants for ecosystems. Trace elements, especially toxic metals deposited on plants and into soil or water, can cause substantial damage to the environment and human health due to their transfer and accumulation in food chains.

This study aimed to determine the amount and the composition of dry deposition in a residential area in Bucharest, organized in summer of 2016, according toDirective 2004/107/EC transposed into Romanian legislation by Law No. 104/2011 regarding the ambient air quality.

The dry deposition samples were collected in accordance with SR EN 15841-2010 Standard.

The major elements $\left(\mathrm{Ca}^{2+}, \mathrm{K}^{+}, \mathrm{Mg}^{2+}\right)$ and trace metals $(\mathrm{Zn}, \mathrm{Fe}, \mathrm{Al}, \mathrm{Ni}, \mathrm{Mn}, \mathrm{Cr}, \mathrm{Cu}, \mathrm{Pb}$ and $\mathrm{Cd}$ ) were determined by atomic absorption spectrometry equipped with a in graphite furnace and inductively coupled plasma optical emission spectrometry (ICP-OES), after acid digestion.

$\mathrm{Al}$ and $\mathrm{Fe}$ were recorded as the dominant metallic elementsin dry deposition followed by $\mathrm{Zn}, \mathrm{Ni}, \mathrm{Cu}, \mathrm{Pb}$, and $\mathrm{Cr}$. This study suggests that earth crust and anthropogenic activities such as motor vehicles were the main sources of dust fall in the study area.
\end{abstract}

Key words: atmospheric deposition, chemical speciation, dry deposition

\section{Introduction}

The atmosphere is an environment in which pollutants are difficult to control once arrived, they quickly disperses according to many factors.

Most of these pollutants in the atmosphere are transferred to soil, vegetation, water, buildings etc., becoming a form of atmospheric deposition with sometimes major environmental impact [1]. Deposition is the final pathway by which pollutants are removed from the atmosphere thus achieving a self-purification of the atmosphere.

Atmospheric pollutants are transferred to the ground by two pathways: dry and wet deposition.

Dry deposition includes the following processes: atmospheric turbulent diffusion, adsorption, absorption, impaction and gravitational settling. The dry deposition process is affected by the type of underlying surface and surface conditions [2].

The dust may include a broad range of chemical species, organic and inorganic compounds. The pollutants that dominates the atmospheric dry deposition are: particulate matter, metals, total phosphorous, $\mathrm{Ca}^{2+}, \mathrm{Mg}^{2+}$, and $\mathrm{K}^{+}$, of organic micropollutants (polycyclic aromatic hydrocarbons, polychlorobiphenyls, polybromodiphenyl ethers and dibenzofurans) [3].

Dry depositions are generally influenced by climate conditions and also by dust and air pollution sources [4]. 
According to Law 104/2011, accumulated atmospheric deposition (total or bulk deposition) means the total mass of pollutants which is transferred from the atmosphere to surfaces (e.g. soil, vegetation, water, buildings, etc.) in a given area within a given time[5].

A dry deposition is a main carrier of heavy metals in the atmosphere and a source of their presence in the soil and surface water. Quantifying the heavy metal concentrations and their solubility in dry and wet deposition samples is part of atmospheric research. Soluble fractions of the deposited air pollutants are important in food chain mechanisms as heavy metals may cause ecotoxic impacts [6].

This is due to the fact that heavy metals are not biodegradable pollutants and, once they reach a certain concentration, are quite harmful to the environment. Thus, this makes heavy metals a potential risk to human health through the food chain. During the past few years, a large amount of work has been carried out in different parts of the world to assess the environmental pollution by heavy metals in soil, vegetation and environment. In urban air, these metals originate mainly from vehicular and industrial emission. Metal pollutants are emit into the atmosphere from numerous sources including combustion of fossil fuels, metals smelter and alloy refineries, cement manufacturing plants and municipal incinerators. Metal and metallic compounds are emitted in the atmosphere in three distinct physical forms: solid particulate matter, liquid droplets (mists) and vapours [7].

This article aims to present the preliminary results obtained in a research study regarding air deposition; were studied the dried deposits, their chemical composition and possible pollution sources using information obtained by calculating the enrichment factor, EFi.

\section{Experimental}

The tests were done in a residential area on the outskirts of Bucharest, in an area with low traffic, showed in Figure 1. Where, any air pollutant emissions may be due to household activities and emissions from the bread factory located in the immediate vicinity.

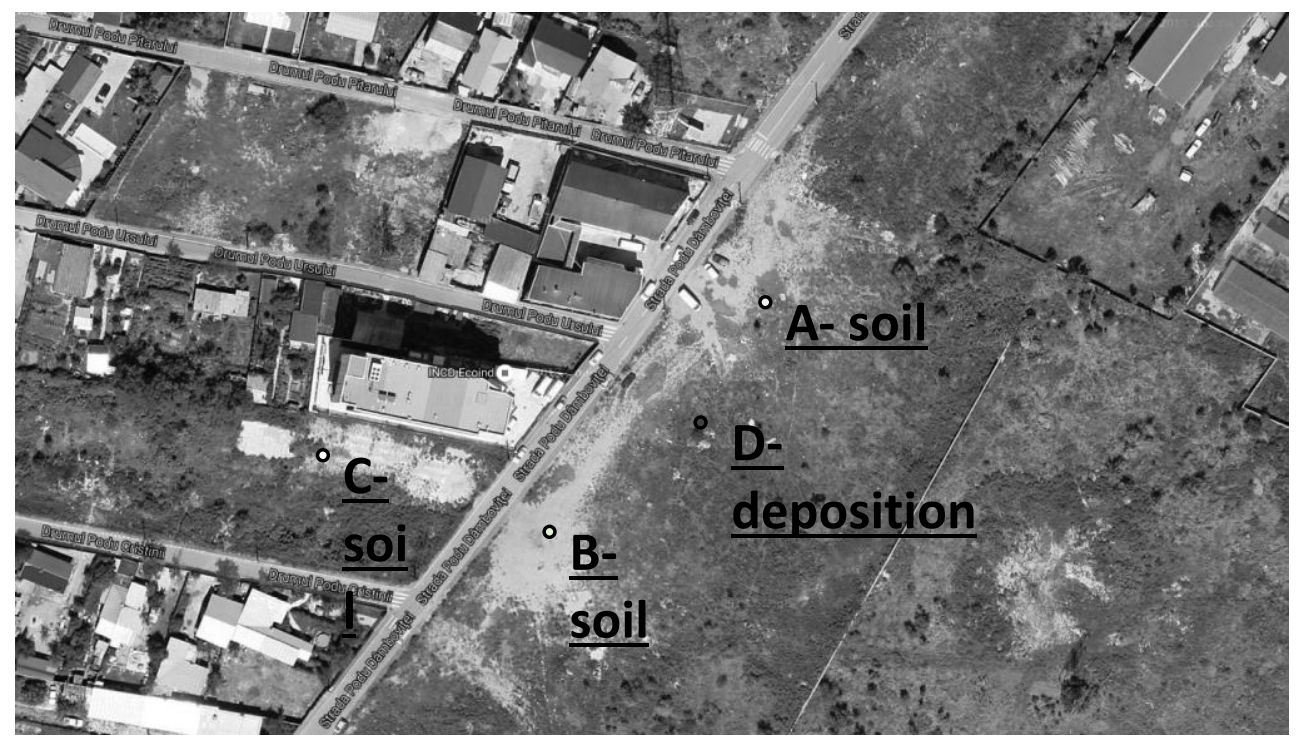

Figure1. Sampling area for the dry depositions and soil samplers

In the month July, 2016, were effectuate two types of experiments: i) the collection and analysis dry deposition and, ii) the collection and analysis of three soil samples to identify the contribution of resuspension phenomenon to the dry deposition concentration. 
The dry depositions were collected 25 days in July, the hottest and driest month of the year. During the sampling period, the ambient air average temperature and humidity were $25.4^{\circ} \mathrm{C}$ and $58 \%$. It should be noted that the measurements represent dry deposition only, as there were no rainfall during the sampling period and the dust samples were collected in a cylindrical plastic containers, $\varnothing 12 \mathrm{~cm}$ (Figure 2). The colectors for metal determination were soaked in 10\% (v/v) nitric acid, rinsed with ultrapure water with resistivity of. $18.2 \mathrm{M} \Omega \cdot \mathrm{cm}$, and oven-dried to eliminate potential contamination as part of the QA/QC program.

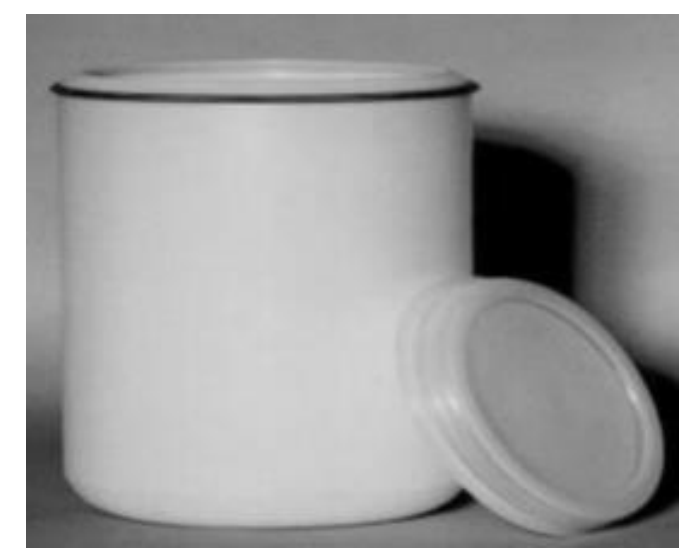

Figure 2. Colector for dry deposition

Dry depositions were removed with ultrapure water from the collecting devices. In this form some samplers were put to evaporation at $105^{\circ} \mathrm{C}$ to determine the dry depositions concentration in air in accordance with STAS 10195-75 [8]; others were passed with a vacuum pump onto filters, being prepared for the wanted analytical method.

In the same time with the dry deposition samples, were also taken soil samples. These were prelevated at $3 \mathrm{~cm}$ depth in three points (A, B and C) and collected in polyethylene bags. After collection, the samplers were brought to the laboratory for further analytical analysis. This is it analyzed in parallel with atmospheric deposition for determine the index enrichment since $\left(\mathrm{EF}_{\mathrm{i}}\right)$. The major elements $\left(\mathrm{Ca}^{2+}, \mathrm{K}^{+}, \mathrm{Mg}^{2+}\right)$ were analyzed using ion chromatography model DIONEX5000+, employing the procedure described by the SR CEN/TR 16269-2015 [9]. The trace metals ( $\mathrm{Zn}, \mathrm{Fe}, \mathrm{Al}, \mathrm{Ni}, \mathrm{Mn}, \mathrm{Ti}, \mathrm{Cr}, \mathrm{Cu}, \mathrm{Pb}, \mathrm{Cd}$ ) were analyzed using atomic absorption spectrometer 280 FS VARIAN equipped with a graphite furnace (PSD-120) and inductively coupled plasma optical emission spectrometry (ICP-OES) Optima 5300DV Perkin Elmer Spectrometer, following the procedure described by the SR EN 15841-2010 [10].

The concentration of each metal was calculated using the mass of analyte, the surface area of the collector and the sampling time, $\left(\mu \mathrm{g} /\left(\mathrm{m}^{2} \mathrm{day}\right)\right.$.

\section{Results and Discussion}

\subsection{Dry depositions and their chemical composition}

For the tested period the amounts of dry deposition was $4,71 \mathrm{gm}^{-2} \cdot \mathrm{month}^{-1}$, which is under the limit imposed by law in our country of $17 \mathrm{gm}^{-2} \cdot \mathrm{month}^{-1}$ [11], specific to a residential area without major sources for particle matter and dust. 
Results regarding the concentration of metals from dry depositions are presented in Table 1 and Figure 3.

Table 1. Metals concentration from dry depositions

$\begin{array}{llllllll}\text { metal } & \mathrm{Al} & \mathrm{Cd} & \mathrm{Cr} & \mathrm{Cu} & \mathrm{Fe} & \mathrm{Mn} & \mathrm{Ni} \\ \boldsymbol{\mu \mathrm { g } / \mathrm { g }} & 7155.25 & 1.13 & 26.48 & 64.78 & 10797.09 & 314.89 & 54.08 \\ \mu \mathrm{gm}^{-2} \text { day }^{-1} & 1123,7 & 0,2 & 4,2 & 10,2 & 1695,6 & 49,5 & 8,5 \\ \text { metal } & \mathrm{Pb} & \mathrm{Ti} & \mathrm{Zn} & \mathrm{Ca}^{2+} & \mathrm{Mg}^{2+} & \mathrm{Na}^{+} & \mathrm{K}^{+} \\ \boldsymbol{\mu \mathrm { g } / \mathbf { g }} & 56.89 & 286.73 & 319.96 & 20033.80 & 3014.87 & 2320.87 & 7154.12 \\ \mu \mathrm{gm}^{-2} \text { day }^{-1} & 8,9 & 45 & 50,2 & 3146,1 & 473,5 & 364,53 & 1123,5\end{array}$

The dry deposition fluxe in $\mathrm{Ca}^{2+}, \mathrm{K}^{+}, \mathrm{Na}^{+}, \mathrm{Mg}^{2+}, \mathrm{Fe}, \mathrm{Al}$ are shown in Figure $3 \mathrm{a}$, and $\mathrm{Zn}, \mathrm{Ni}, \mathrm{Mn}, \mathrm{Cr}$, $\mathrm{Cu}, \mathrm{Pb}, \mathrm{Ti}$ and $\mathrm{Cd}$ are shown in Figure $3 \mathrm{~b}$.
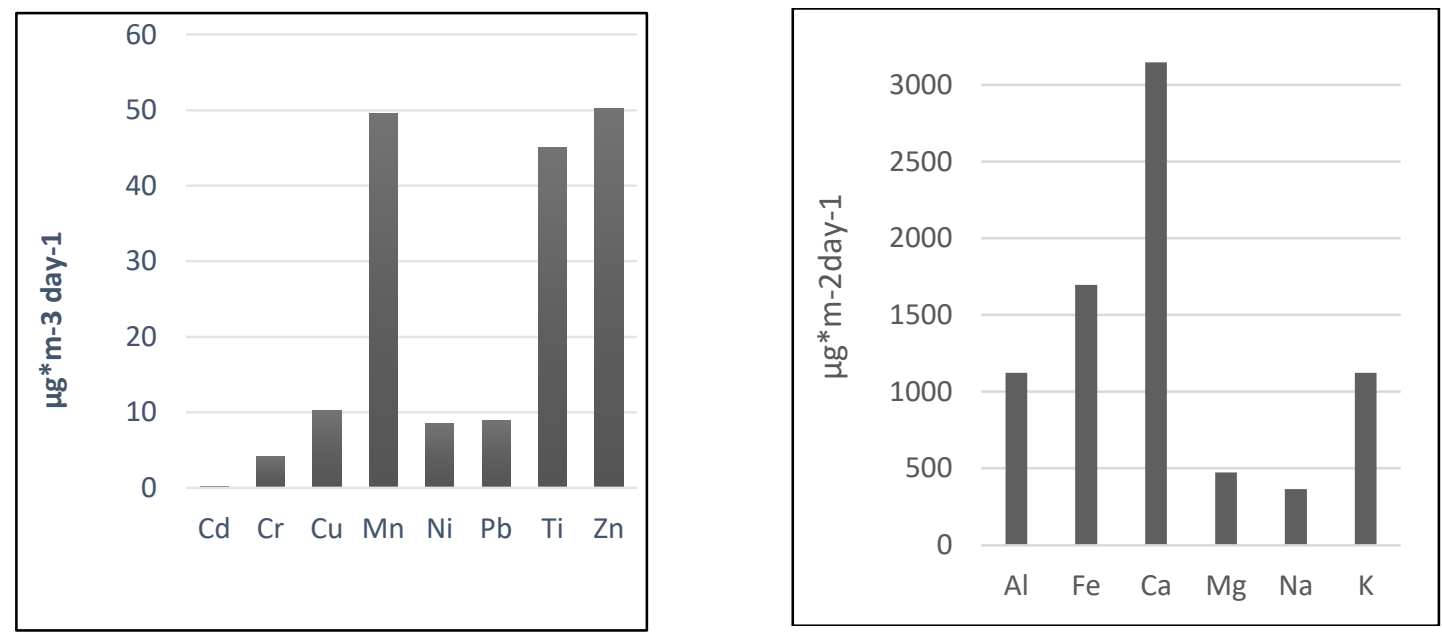

Figure 3. Variation of $\mathrm{Ca}^{2+}, \mathrm{K}^{+}, \mathrm{Na}^{+}, \mathrm{Mg}^{2+}, \mathrm{Fe}, \mathrm{Al}$ in dry deposition fluxe(a), variation of $\mathrm{Zn}, \mathrm{Ni}$, $\mathrm{Mn}, \mathrm{Cr}, \mathrm{Cu}, \mathrm{Pb}, \mathrm{Ti}$ and $\mathrm{Cd}$ in dry deposition fluxe(b)

The highest average fluxes found for the elements were in the order:

$\mathrm{Ca}>\mathrm{Fe}>\mathrm{Al}>\mathrm{K}>\mathrm{Mg}>\mathrm{Na}>\mathrm{Zn}>\mathrm{Ti}>\mathrm{Mn}>\mathrm{Cu}>\mathrm{Pb}>\mathrm{Ni}>\mathrm{Cr}>\mathrm{Cd}$

It can be seen that the metals which usually are found in the Earth's crust are the most abundant $(\mathrm{Ca}>\mathrm{Fe}>\mathrm{Al}>\mathrm{K}>\mathrm{Mg}>\mathrm{Na}$ ) while metals generated mainly by human activities $(\mathrm{Zn}>\mathrm{Ti}>\mathrm{Mn}>$ $\mathrm{Cu}>\mathrm{Pb}>\mathrm{Ni}>\mathrm{Cr}>\mathrm{Cd}$ ) are found in smaller quantities, suggesting as possible source the resuspension phenomenon and the soil erosion in the area.

In order to verify this theory, three soil samples were sampled from the area and analyzed (A, B and C) (Fig. 1) and the results are presented in Table 2 and Figure 4. 
Table 2. Concentrations of metals from soil sample A, B and C $(\mu \mathrm{g} / \mathrm{g})$

\begin{tabular}{|c|c|c|c|c|c|c|c|}
\hline Sol Metal & Al & Cd & $\mathrm{Cr}$ & $\mathrm{Cu}$ & $\mathrm{Fe}$ & $M n$ & $\mathbf{N i}$ \\
\hline A & 12850.35 & 0.41 & 54.70 & 60.02 & 25363.13 & 616.04 & 108.94 \\
\hline B & 8338.67 & 0.31 & 21.43 & 41.64 & 18288.56 & 487.81 & 18.68 \\
\hline $\mathrm{C}$ & 4353.745 & 0.10 & 15.17 & 11.57 & 11711.96 & 182.94 & 13.72 \\
\hline Sol Metal & $\mathrm{Pb}$ & $\mathbf{T i}$ & $\mathrm{Zn}$ & $\mathrm{Ca}^{2+}$ & $\mathrm{Mg}^{2+}$ & $\mathrm{Na}$ & $\mathbf{K}^{+}$ \\
\hline A & 32.67 & 345.26 & 233.68 & 14127.64 & 5158.62 & 65.49 & 3493.85 \\
\hline B & 18.28 & 252.25 & 255.92 & 15251.93 & 3183.15 & 52.84 & 2118.03 \\
\hline C & 6.46 & 367.58 & 29.00 & 8208.05 & 1757.51 & 180.48 & 1247.76 \\
\hline
\end{tabular}

The highest average concentration for the elements in soil were, in the following order: $\mathrm{Al}>\mathrm{Fe}>$ $\mathrm{Ca}>\mathrm{Mg}>\mathrm{K}>\mathrm{Mn}>\mathrm{Ti}>\mathrm{Zn}>\mathrm{Na}>\mathrm{Pb}>\mathrm{Ni}>\mathrm{Cr}>\mathrm{Cu}>\mathrm{Cd}$
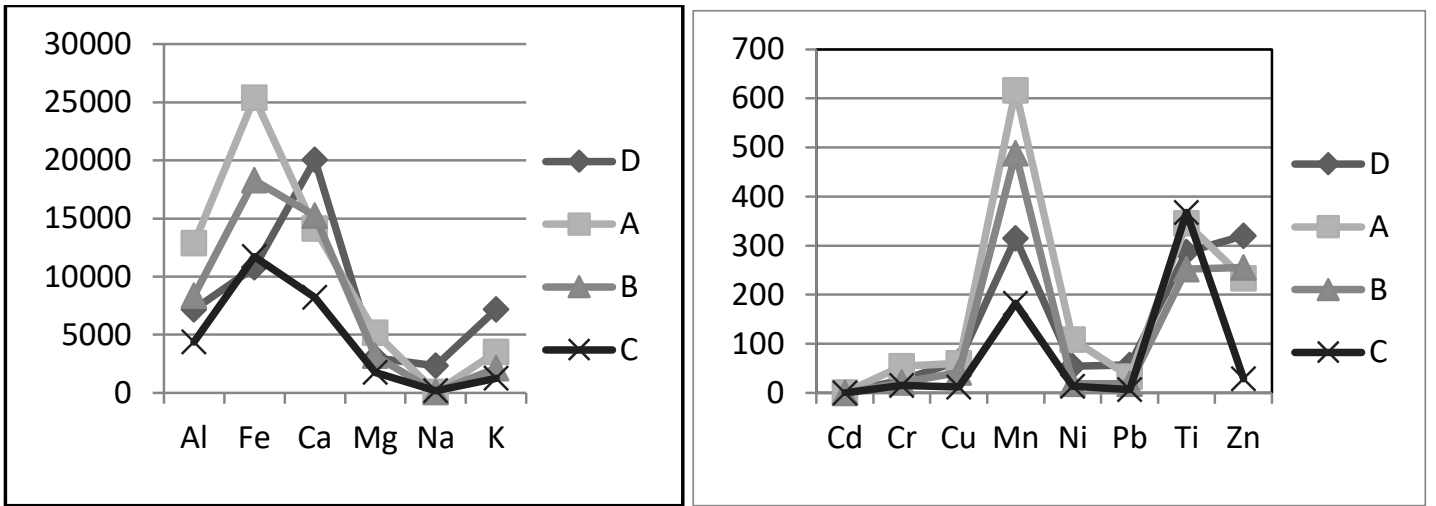

Figure 4. Metals concentration variation in dry depositions (D) and the soil samples $(A, B, C)$ are showed in Figure $4 \mathrm{a}$ and $\mathrm{b}$.

It can be observed that both in dry deposits and soils samples analyzed, we found the same five metals: $\mathrm{Al}, \mathrm{Fe}, \mathrm{Ca}, \mathrm{Mg}$ and $\mathrm{K}$, as having the highest concentrations, which leads us to believe that most metals found in dry deposits are due to resuspension and soil erosion. To this are added anthropogenic sources from urban areas whose influence is felt in the periphery.

This theory is supported by the results of Pearson Correlation Analysis (Table 3) indicating correlations between good and very good soil composition and deposition area and the enrichment factor values (Figure 5).

Table 3. Pearson Correlation Analysis results for soil and dry deposition

\begin{tabular}{|l|l|r|r|r|r|}
\hline \multicolumn{2}{|c|}{} & \multicolumn{1}{|c|}{ D } & \multicolumn{1}{c|}{ A } & \multicolumn{1}{c|}{ B } & \multicolumn{1}{c|}{ C } \\
\hline \multirow{2}{*}{$\mathrm{D}$} & Pearson Correlation & 1 & $.791^{*}$ & $.885^{*}$ & $.847^{*}$ \\
& Sig. (2-tailed) & & .000 & .000 & .000 \\
\hline \multirow{2}{*}{$\mathrm{A}$} & Pearson Correlation & $.791^{* *}$ & 1 & $.975^{*}$ & $.983^{*}$ \\
& Sig. (2-tailed) & .000 & & .000 & .000 \\
\hline \multirow{2}{*}{$\mathrm{B}$} & Pearson Correlation & $.885^{*}$ & $.975^{* *}$ & 1 & $.995^{*}$ \\
& Sig. (2-tailed) & .000 & .000 & & .000 \\
\hline \multirow{2}{*}{$\mathrm{C}$} & Pearson Correlation & $.847^{*}$ & $.983^{* *}$ & $.995^{*}$ & 1 \\
& Sig. (2-tailed) & .000 & .000 & .000 & \\
\hline
\end{tabular}

${ }^{* *}$. Correlation is significant at the 0.01 level (2-tailed). 


\subsection{Enrichment factor $\left(E F_{i}\right)$}

The use of an enrichment factor (EF) is a first-step of source identification to differentiate the possible sources of atmospheric trace elements [12].

EF is defined as follows:

$$
E F_{i}=\left(X_{i} / X_{r}\right) \text { dry } /\left(X_{i} / X_{r}\right)_{\text {sou }}
$$

where $\mathrm{EFi}$ is the $\mathrm{EF}$ of element $\mathrm{i}, \mathrm{r}$ is the reference element, $(\mathrm{Xi} / \mathrm{Xr})$ dry is the concentration ratio of element i over the reference element $r$ in dry deposition, and $(\mathrm{Xi} / \mathrm{Xr})$ sou is the abundance ratio of element i over $r$ in source materials (crustal rock).

Enrichment Factor (EF) were calculated for each element using of crustal materials composition with $\mathrm{Ti}$ as the normalizing element. The use of $\mathrm{Ti}$ as a normalizing agent is quite appropriate because it is a crustal element with less anthropogenic influence[13].

Elements with EF $\leq 10$ have a strong natural component while elements with high EF $>10$, have anthropogenic origin, or are due to other natural sources such as marine aerosols[12,13]. The values obtained for the enrichment factor calculated for all the elements are shown in Figure 5.

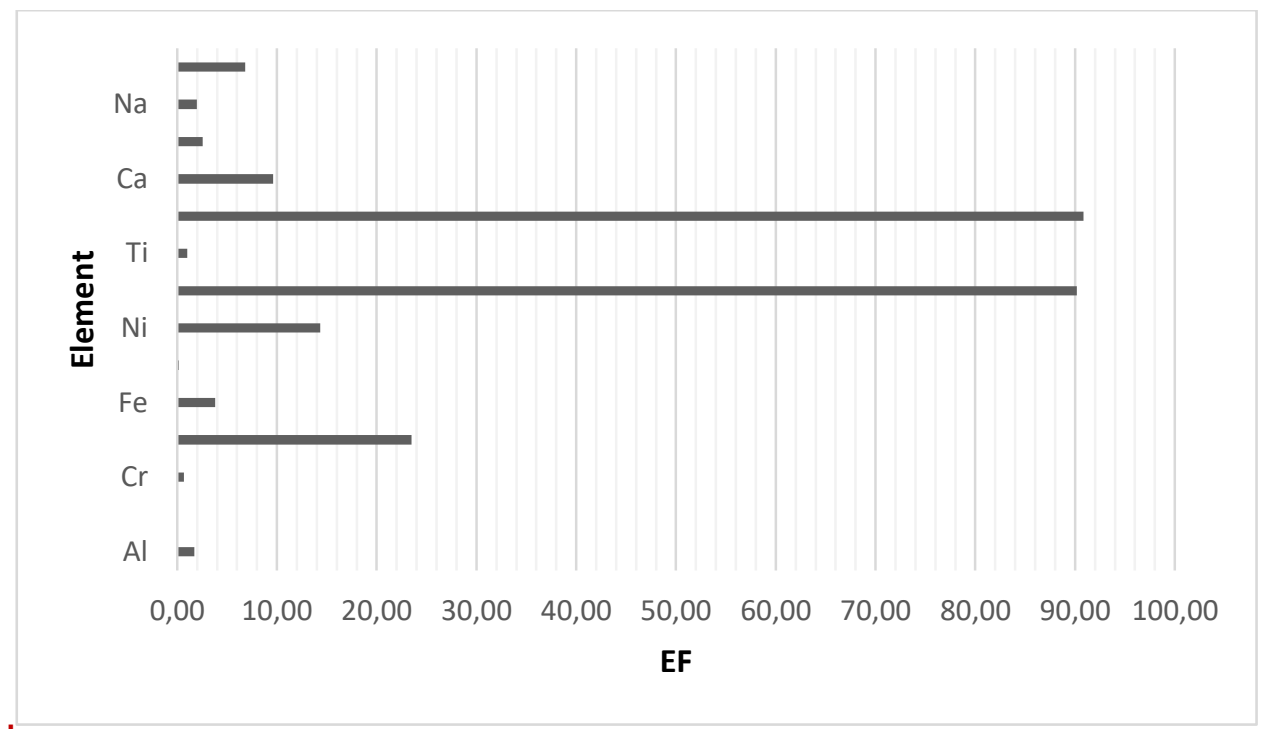

Figure 5. Enrichment factors of elements in dry deposition with Ti as the reference element for crustal material.

It can be seen that the majority of metals from dry deposits have enrichment factor $\mathrm{EFi}<10: \mathrm{Mn}$, $\mathrm{Cr}, \mathrm{Al}, \mathrm{Na}, \mathrm{Mg}, \mathrm{Fe}, \mathrm{K}, \mathrm{Ca}$. This demonstrates once again our suggested theory, according to which the majority of the elements found in dry deposits come from soil erosion and resuspension. There are also four metals enrichment factor $\mathrm{EFi}>10: \mathrm{Ni}, \mathrm{Cu}, \mathrm{Pb}, \mathrm{Zn}$, metals whose presence in dry deposits is due to other anthropogenic sources.

\section{Conclusions}

This paper is a case study on the composition of atmospheric deposition in a residential area, with no significant sources of pollution (traffic, industry, etc). 
Dry deposition samples were prelevated and after laboratory analysis the amount of dry depositions in $\mathrm{g} /\left(\mathrm{m}^{2} \cdot \mathrm{month}\right)$ was below the allowed limit in Romanian law.

The dominant cation was $\mathrm{Ca}^{2+}$, followed by by $\mathrm{K}^{+}, \mathrm{Mg}^{2+}$ and $\mathrm{Na}^{+}$ions.

The dominant trace element was Fe, followed by $\mathrm{Al}, \mathrm{Zn}, \mathrm{Mn}, \mathrm{Cu}, \mathrm{Pb}, \mathrm{Ni}$ and $\mathrm{Cr}$.

From the enrichment factor analysis, composite elements from dry deposition, like: $\mathrm{Ca}^{2+}, \mathrm{K}^{+}, \mathrm{Mg}^{2+}$, $\mathrm{Zn}, \mathrm{Fe}, \mathrm{Al}, \mathrm{Ni}, \mathrm{Mn}, \mathrm{Cr}, \mathrm{Cu}, \mathrm{Pb}$ and $\mathrm{Cd}$; were due to the largely re-suspension of soil in the area studied.

The erosion and resuspension of the soil as main pollution source in the studied area was also sustained by the Pearson Correlation Analysis.

In the case of $\mathrm{Ni}, \mathrm{Cu}, \mathrm{Pb}$ and $\mathrm{Zn}$, external sources (anthropogenic and natural) or pollution due to long distances, were the main cause of their concentration in the samples.

The results presented in this paper are preliminary result in a study we intend to continued for a longer period.

\section{Acknowledgents:}

The authors are grateful for the financial support of project PN 162502 08-2016(Contract no.38N/2016)

\section{References}

1.C. Butean, Zoita M. Berinde, C. Mihali,A. Michnea, A. Gavra and M. Simionescu,2014- Atmospheric Deposition of Copper and Zinc in Maramures County (Romania),ACTA CHEMICA IASI, 22_2, 165-176 ; 2.R. K. Kamble, 2015- Dust fall rate and its composition in Chandrapur industrial cluster, central India, International Journal of Environment, Volume-4, Issue-3;

3.G. Settimo and G. Viviano,2015 - Atmospheric depositions of persistent pollutants: methodological aspects and values from case studies, Ann Ist Super Sanita,Vol. 51, No. 4: 298-304;

4.M. AL-Harbi, 2015 --Characteristics and composition of the falling dust in urban environment, Int. J. Environ. Sci. Technol. (2015) 12:641-652

5.Legea 104/2011-on ambient air quality (Romanian Law);

6. Thabet A. Mohamed, Mohamed Abuel-Kassem Mohamed, Ragab Rabeiy, Mahmoud A. Ghandour,2013- A Study of Heavy Metals in the Dust Fallaround AssiutFertilizer Plant, Journal of Environmental Protection, 4, 1488-1495;

7.Kavita Tiwari, Anupama Pandey and J. Pandey, 2008-Atmospheric deposition of heavy metals in a seasonally dry tropical urban environment (India), Journal of Environmental Research And Development, Vol. 2 No. 4;

8.STAS 10195-75) - Purity of air. The determination of dry deposition(Romanian National Standard);

9.SR CEN/TR 16269-2015-Ambient air - Guide for the measurement of anions and cations in PM2,5;

10.SR EN 15841-2010 - Ambient air quality - Standard method for determination of arsenic, cadmium, lead and nickel in atmospheric deposition;

11.STAS 12574-87- Air in procted areas. Quality conditions (Romanian National Standard);

12.Guojie Xu , Yuan Gao 2014 - Atmospheric trace elements in aerosols observed over the Southern Ocean and coastal East Antarctica, Polar Research, 33,

13.C.A. Onwudiegwu, G.C. Ezeh, I.B. Obioh, 2016 - Trace Metals in Total Atmospheric Deposit ions (TAD) of a Nigerian Island, Journal of Atmospheric Pollution, Vol. 4, No. 1, 15-22; 